\title{
Analisis Historis Manajemen Dakwah Rosulullah Saw dalam Piagam Madinah
}

\author{
Ridwan Rustandi \\ Syarif Sahidin \\ UIN Sunan Gunung Djati, Bandung \\ STAI Muhammadiyyah, Bandung \\ ridwanrustandiuinsgd.ac.id
}

\begin{abstract}
This study aims to explore the values of the peace negotiations contained in the Medina charter as part of the management of the missionary Rasulullah Saw. Negotiations are an alternative method of Islamic da'wah carried out by paying attention and considering various socio-cultural-political conditions. One of the peace talks that was carried out by Rasulullah Saw who was laden with the values of Islamic da'wah was the Medina Charter. This research uses a qualitative approach that is carried out through the content analysis method. The study was conducted by searching the literature to collect data related to the research topic. The results showed that the peace negotiations in the history of Islamic da'wah were carried out by Rasulullah Saw as a form of missionary management with an orientation to reach an agreement and embody social cohesiveness. The Medina Charter as a peace treaty contains various values that can be applied in social life including 1) the value of tolerance as a social glue; 2) the value of humanity as a foundation; 3) the value of God (transcendence) as the foundation of life; and 4) the value of liberation as a manifestation of creation. These four values have a strong significance in the context of contemporary da'wah, especially in dealing with the potential for conflict in society.
\end{abstract}

Keywords: Da'wah Management, Peace Negotiations, Medina Charter

\section{A. Pendahuluan}

Rosulullah Muhammad Saw didaulat sebagai utusan Allah Swt dalam mengemban misi nubuwwah. Misi tersebut dilakukan dalam rangka membangun kesadaran teologis manusia. Kesadaran tersebut dibangun di atas fondasi nilainilai agama Islam sebagai doktrin dan peradaban yang harus ditegakkan di atas ketauhidan. Upaya dalam mengemban misi nubuwwah ini adalah melalui penyebaran agama Islam (dakwah) agar terwujud kehidupan manusia yang berorientasi pada kebaikan (amar ma'ruf) dan pencegahan terhadap segala bentuk keburukan yang dapat merusak kehidupan manusia (nahi munkar). Selanjutnya, 
upaya amar maruf dan nahi munkar ini dilakukan oleh seluruh kaum muslimin sebagai titah Allah Swt yang berlaku sepanjang zaman (Qs.03:104).

Titah ini diterjemahkan ke dalam beragam lingkup kehidupan manusia, sehingga mudah diterima, dipahami, diinternalisasi dan diimplementasikan dalam wujud amal (perbuatan). Pada titik inilah, misi nubuwwah nabi Muhammad Saw bersandar pada penyadaran teologis yang berdampak pada kesadaran humanis. Dakwah Islam yang ditegakkan sebagai upaya membangun risalah transformatif yang bernilai dalam kehidupan manusia dalam memenuhi kebutuhan sosialnya. Sebab bagaimanapun dakwah teologis harus menekankan pada kebutuhan sosiologis sehingga nilai-nilai adiluhung dalam ajaran Islam termanifestasikan secara nyata.

Dakwah transformatif Rosulullah Saw adalah wujud implementasi risalah Islam dalam kehidupan sosial. Hal ini berorientasi pada pengembangan masyarakat $^{1}$ yang berlandaskan pada pola pikir dan tingkah laku masyarakat secara emansipatif dengan berpedoman pada ajaran Islam. Dalam hal ini, dakwah transformatif Rosulullah dilakukan sebagai bagian dari aktifitas sosial yang dekat dengan keseharian masyarakat. Dakwah diorientasikan sebagai upaya untuk menciptakan masyarakat ideal. Yakni, sebuah tatanan masyarakat yang memiliki ketauhidan yang kuat, fondasi keimanan yang utuh, sekaligus memliki amalan yang mulia sesuai dengan fondasi keimanannya. Dalam konteks Indonesia, keberadaan majelis taklim sebagai forum kajian dan transfer pengetahuan keislaman menjadi salah satu upaya untuk membumikan nilai-nilai keislaman dalam keseharian kehidupan masyarakat Indonesia. Hal ini sebagai bentuk bagaimana pentingnya menanamkan fondasi pemikiran, mentalitas, keterampilan, pengetahuan dan kehidupan sosial yang didasarkan pada nilai-nilai keislaman.

\footnotetext{
${ }^{1}$ Rosulullah diutus oleh Allah Swt untuk menyempurnakan akhlak (liuttamima makaarimal akhlaq). Kesadaran transformatif ini dibangun di atas nilai-nilai Islam yang menghargai martabat manusia. Dalam rangkaian sejarah jazirah Arab pra Islam datang, kita dapati bagaimana penghargaan terhadap nilai-nilai kemanusiaan begitu rendah. Maka, Islam datang dengan membawa risalah untuk menempatkan manusia dalam posisi terhormat secara adil dan amanah.
} 
Rosulullah Saw adalah teladan utama bagi seluruh umat Islam dalam menyampaikan risalah Islam. Dalam beberapa kesempatan Rosulullah Saw selalu mendakwahkan Islam sesuai dengan konteks dan kebutuhan ${ }^{2}$. Manajemen dakwah yang dilakukan oleh Rosulullah Saw berpedoman pada kitab dakwah utama yakni al-qur'an yang mengajarkan bagaimana pentingnya melakukan amar maruf dan nahi munkar dengan memperhatikan segmentasi dan kebutuhan objek dakwah (madh'u). Teladan dakwah yang Rosulullah Saw lakukan sangat variatif. Rosulullah selalu memperhatikan kondisi objeknya, latar sosial, tingkat pengetahuan dan kecakapan, status ekonomi, termasuk dalam hal pengembangan strategi (siyasah) atau politik dakwahnya. Hal ini dilakukan agar risalah yang disampaikan menyerap pada hati objeknya, sehingga mau menerima dan mengamalkannya. Secara umum, dengan merujuk surat An-nahl ayat 125 para ahli mengklasifikasikan metode dakwah Rosulullah ke dalam tiga bentuk, yakni : metode hikmah, mauidzah hasanah dan mujadalah ${ }^{3}$.

Implementasi ketiga metode dakwah di atas, dilakukan melalui berbagai forum, cara, dan media variatif sesuai dengan segmentasi dan kebutuhan madh'u. Derivasi metode dakwah tersebut dilakukan misalnya melalui lembaga pendidikan, lembaga dakwah, lembaga keuangan, lembaga sosial, ormas Islam, partai politik, dan lembaga lainnya. Ini menunjukkan bagaimana dakwah dapat dilakukan melalui proses pelembagaan yang dapat menopang nilai-nilai pengetahuan, keterampilan, mentalitas dan sikap atau tindakan seseorang agar berkesesuaian dengan nilai-nilai Islam. Selain itu, bermekarannya cara dan media dakwah lainnya seperti majelis taklim, forum ilmiah Islami, study club, pelatihan da'i (tamhidul mubalighin), dialog interaktif, debat, maupun melalui teknik dan forum negosiasi atau perundingan adalah model-model dakwah yang

\footnotetext{
${ }^{2}$ Narasi sejarah dakwah Rosulullah Saw seringkali kita dapati bagaimana metode, model dan media dakwah Rosulullah Saw yang variatif. Suatu ketika Rosulullah pernah berdakwah secara tersembunyi kemudian terang-terangan. Suatu masa Rosulullah pernah berdakwah dengan lisan, tulisan kemudian dengan uswah. Suatu saat Rosulullah berdakwah pada arab badui (kampung), kaum elite, ekonom, dan lain sebagaimanya. Pedoman dakwah utama (al-qur'an) dan hadits nabi Muhammad Saw menunjukkan bagaimana variasi manajemen dakwah yang dilakukan Rosullah selalu sesuai dengan kebutuhan objeknya.

${ }^{3}$ Sambas, S. dkk. 2009. Dimensi Ilmu Tabligh. Bandung : WIdya Padjadjaran, hlm. 113.
} 
dikembangkan agar nilai-nilai al-qur'an dan as-sunnah senantiasa sejalan dan membumi dalam kehidupan masyarakat. Dengan kata lain, dakwah Islam adalah bagian sentral dalam ajaran Islam agar terwujud kehidupan yang par excellence dengan menerapkan konsep dan nilai Islam secara syumuli (kaffah).

Salah satu model manajemen dakwah yang dicontohkan oleh Rosulullah Saw adalah melalui teknik negosiasi atau perundingan damai. Dalam lintasan sejarah dakwah Rosulullah Saw, perundingan adalah jalan damai yang dilakukan untuk menegakkan dakwah Islam dengan mempertimbangkan beberapa kemungkinan dan kebutuhan. Pada umumnya, perundingan dilakukan melalui skema perencanaan, pengelolaan dan penerapan dakwah Islam. Perundingan yang dilakukan Rosulullah Saw adalah perundingan-perundingan dengan kafir quraisy. Beberapa perundingan yang pernah dilakukan pada masa Rasulullah di antaranya bait aqabah I dan II ketika Rosulullah berusaha mempersaudarakan dua suku bangsa besar antara bani Auz dan Khazraz, perjanjian Hudaibiyyah adalah genjatan senjata antara umat Islam dengan kafir quraisy, dan piagam Madinah berupa perundingan mengenai hak dan kewajiban umat Islam dan YahudiNashrani sebagai warga Negara Madinah.

Islam memandang perundingan sebagai sesi hujjah (dialog konstruktif) antara Muslim dan bukan Muslim dalam menyelesaikan konflik secara kritis, emansipatif, mendalam dan berorientasi pada tujuan bersama. Perundingan atau negosiasi adalah bentuk akomodatif dalam proses penyelesaian konflik. Manajemen dakwah Rosulullah Saw yang dilakukan melalui perundingan menunjukkan bagaimana sebuah upaya penegakkan risalah Islam pada masa Rosulullah Saw begitu sangat penting sehingga mengandalkan kecerdasan, mentalitas dan keterampilan dalam membaca, menganalisis dan memetakan berbagai kemungkinan yang terjadi pada saat risalah Islam disebarkan. Sehingga, orientasi dakwah Islam dapat terwujud sebagaimana yang dicita-citakan.

Konsep perundingan dalam Islam merupakan lambang keyakinan dalam menguatkan persaudaraan, mengikat silaturahmi, membangun persahabatan dan kerja sama serta memudahkan urusan dalam penyelesaian konflik. Perundingan 
adalah upaya harmoni dan selaras untuk menyatupadukan dalam rahmat Islam (Qs.60:8-9) ${ }^{4}$. Perundingan menjadi simbol kekuatan umat Islam sebagai penganut ajaran agama yang mencintai perdamaian. Potensi konflik (vertikal dan horizontal) yang terjadi pada masyarakat adalah dinamika sosial yang menghendaki adanya penyelesaian. Islam sebagai agama yang adiluhung memberikan solusi yang tegas dalam penyelesaian konflik. Adanya konsep tabayyun dalam Islam merupakan salah satu nilai agama yang mengajarkan tentang perdamaian dan persatuan sosial ${ }^{5}$. Dengan begitu, perundingan dalam Islam berorientasi pada perwujudan masyarakat yang memiliki kohesivitas sosial yang tinggi, yakni masyarakat yang menanggalkan pertentangan demi terwujudnya keharmonisan dalam kehidupannya.

Konflik antara pasukan Amerika dan Taliban di Afghanistan, Perang Israel dan palestina di jalur Gaza, Perang Suriah, Konflik Muslim Myanmar dan umat Budha, Konflik Muslim di Pattani Thailand, Konflik Muslim dan Kristen Tolikara Papua, serta beragam konflik lainnya yang melibatkan Muslim dan bukan Muslim adalah sebuah fakta sosial dan fakta sejarah yang tidak bisa dipungkiri. Konflik-konflik itu terjadi mengatasnamakan agama, sehingga berpotensi mendiskreditkan agama tertentu, terutama Islam. Belum lagi, bentuk teror yang pernah terjadi di beberapa negara, misalnya aksi teror WTC di Amerika Serikat, Teror Mumbai India, aksi Bom Bali di Indonesia, aksi Teror hotel Marriot Kuningan Jakarta, dan bentuk-bentuk teror lainnya menunjukkan bahwa konflik atas nama agama menjadi sebuah gejala yang berkembang di masyarakat. Konflik seolah menjadi sebuah keniscayaan yang berujung pada kekerasan. Yang mengkhawatirkan bilamana konflik terjadi mengatasnamakan

\footnotetext{
${ }^{4}$ Firman Allah yang bermaksud, "Allah tiada melarang kamu berbuat baik dan berlaku 'adil terhadap orang-orang yang tidak memerangi kamu dalam urusan agamamu, dan tiada pula mengusir kamu dari kampung halamanmu. Sesungguhnya Allah Mengasihi orang yang berlaku adil. Sesungguhnya Allah hanya melarang kamu mengangkat wali (pemimpin) dari orang-orang yang memerangi kamu, kerana agamamu dan mengusir kamu dari kampung halamanmu. Barangsiapamenjadikan mereka sebagai kawan, maka mereka itulah orang yang zalim.”

${ }^{5}$ Konsep tabayyun sebagaimana dijelaskan Allah Swt dalam Q.s Al-Hujurat ayat 11 menunjukkan bagaimana ketegasan ajaran Islam sebagai agama yang menghendaki adanya kohesi dan koherensi sosial. Pada konteks lainnya, dakwah Islam dilakukan melalui jalan-jalan perdamaian. Adapun jihad melalui qital atau perang adalah cara terakhir yang ditempuh bilamana tidak adanya kesepahaman dengan pihak yang menentang untuk menerima dakwah Islam.
} 
agama. Maka pada titik inilah perlu dirumuskan manajemen dakwah berbasis perundingan damai sebagai salah satu alternatif dalam mengembangkan modelmodel resolusi konflik yang pernah dilakukan oleh Rosulullah Saw.

Penelitian tentang manajemen konflik dalam dakwah Islam pernah dilakukan sebelumnya, di antaranya penelitian tentang manajemen konflik dalam perspektif Dakwah Islam (Waedulloh, 2014). Penelitian ini menunjukkan bahwa manajemen konflik dilakukan melalui prinsip-prinsip dakwah Islam dengan mengedepankan akurasi data (tabayyun), kesepakatan bersama (musyawarah), dan perdamaian (Ishlah). Penelitian tentang manajemen organisasi dakwah dalam resolusi konflik (Yuliyatun, 2016). Penelitian terfokus pada pengembangan strategi organisasi dakwah Islam dalam melakukan resolusi konflik dan pencegahan terhadap intoleransi dan radikalisme atas nama agama. Organisasi dakwah Islam yang dimaksud baik itu berbasis organisasi masyarakat Islam, organisasi mahasiswa dan kepemudaan Islam, partai politik, dan lain-lain. Penelitian tentang manajemen dakwah Rosulullah Saw pada gelombang Makkah (Cucu, 2016; Basri, 2014). Penelitian ini menganalisis berbagai penerapan prinsip-prinsip manajemen dalam gerakan dakwah Rosulullah Saw pada periode Makkah. Salah satunya melalui penerapan strategi menghindari permusuhan yang dilakukan oleh Rosulullah Saw untuk menguatkan fondasi dakwah Islam pada periode tersebut. Selain itu, manajemen dakwah yang dilakukan oleh Rosulullah Saw pada periode Makkah ini adalah dengan membangun kesadaran teologis secar personal dan membentuk kelompok dakwah (kutlah) yang memiliki mentalitas dan kecakapan di atas kalimat tauhid untuk menyebarkan risalah Islam.

Penelitian tentang penerapan manajemen strategi dalam dakwah Rosulullah Muhammad Saw (Antariksa, 2017). Penelitian ini menganalisis penerapan strategi dakwah Rosulullah Saw baik pada periode Makkah maupun periode Madinah. Hasil penelitian menunjukkan salah satu penerapan strategi dakwah Rosulullah pada periode Madinah awal adalah melalui perundingan damai yang terkandung dalam Piagam Madinah dan Perjanjian Hudaibiyyah. 
Penelitian tentang manajemen dakwah Rosulullah Saw pada periode Madinah dilakukan dengan melihat sisi strategi dakwah dalam bidang politik dan hukum (Basri, 2015). Penelitian ini menunjukkan bahwa salah satu strategi jihad politik yang dilakukan oleh Rosulullah Saw adalah melalui perundingan yang termaktub dalam Piagam Madinah. Bagaimana konsep jihad menjadi salah satu strategi dakwah dalam membangun hubungan politik luar negeri yang dilakukan oleh nabi Muhammad Saw. Penelitian penerapan tentang manajemen konflik dalam lingkup dakwah dilakukan dengan mengambil sudut pandang kelembagaan. Salah satunya adalah manajemen konflik yang dilakukan di Fakultas Dakwah dan Komunikasi UIN Sunan Kalijaga Yogyakarta (Syarnubi, 2017). Hasil penelitian menunjukkan bahwa salah satu manajemen konflik yang dapat dilakukan adalah melalui metode kompromi dengan mengedepankan unsur-unsur persamaan dan kesepakatan bersama.

Penelitian tentang Manajemen Dakwah Rosulullah Saw melalui Perundingan Damai adalah penelitian yang mengambil sudut pandang sejarah dakwah Islam. Penelitian ini terfokus pada upaya menganalisis nilai-nilai dakwah Islam yang menjadi prinsip penerapan manajemen konflik. Penelitian ini dilakukan dengan mengkaji teks atau pasal-pasal yang merujuk pada perundingan antara kaum muslim dan kafir quraisy yang termaktub dalam Piagam Madinah. Peneliti berasumsi bahwa salah satu kesuksesan dakwah Rosulullah Saw adalah melalui perundingan-perundingan yang mengedepankan kesepakatan di atas permusuhan. Nilai-nilai perdamaian tersebut adalah wujud penerapan dakwah Islam yang berorientasi pada cita-cita Rahmatan Lilalamin.

\section{B. Metode Dakwah Rosulullah Periode Makkah dan Madinah}

Berdasarkan bentuknya, cara penyebaran Islam (metode dakwah) yang dilakukan oleh nabi Muhammad Saw dilakukan dalam dua cara, yakni melalui khitobah (lisan) dan kitabah (tulisan). Pada tataran praktiknya, kedua bentuk ini dieksplorasi melalui berbagai teknik, di antaranya melalui dakwah lisan secara langsung, teknik persuratan, mengutus da'i atau mubaligh ke beberapa negara di 
luar jazirah Arab, serta melalui teknik perundingan yang dilangsungkan sesuai dengan konteks sosial dan politik.

Merujuk pada sejarah dakwah nabi Muhammad Saw, setidaknya metode dakwah tersebut dilakukan berdasarkan tahapan-tahapan tertentu (thoriqah) ${ }^{6}$ baik pada periode Mekkah maupun periode Madinah ${ }^{7}$. Dakwah khitobah maupun dakwah kitabah dilakukan oleh Rasulullah dengan orientasi untuk menyampaikan nilai-nilai ajaran Islam sebagai pandangan hidup (worldview) sekaligus fondasi dalam membangun peradaban umat. Penerapan metode dakwah akan berkesesuaian dengan kondisi yang mempengaruhi realitas Islam pada masa itu. Faktor-faktor internal dan eskternal umat Islam seperti jumlah umat Islam secara kuantitas yang masih sedikit, kuatnya pengaruh kafir Quraisy, dan kehadiran risalah Islam yang masih baru merupakan faktor yang dipertimbangkan oleh Rosulullah Saw pada periode Mekkah. Berbeda halnya dengan kondisi internal dan ekternal pada periode Madinah cenderung memiliki kesiapan mentalitas yang kuat, jumlah umat Islam yang semakin bertambah, bergaining position yang semakin tinggi dan diperhitungkan oleh kafir quraisy serta berbagai faktor lain menjadi pertimbangan dalam perencanaan dan pelaksanaan dakwah Islam. Sehingga pada periode Madinah, umat Islam cenderung sudah siap menghadapi perlawanan dan pertentangan dari kafir quraisy termasuk apabila mengharuskan umat Islam untuk jihad ke medan perang.

\section{Manajemen Dakwah Periode Mekkah}

Dakwah khitobah atau metode dakwah melalui lisan dilakukan oleh Rasulullah Saw pada periode Mekkah baik secara sembunyi-sembunyi maupun terang-terangan. Pada kedua kondisi ini, baik secara sembunyi maupun terang-terangan tranmisi pesan ilahiah dilakukan oleh nabi Muhammad Saw masih pada kalangan terbatas. Dimulai dari kalangan keluarga, beberapa pemuda, beberapa hamba sahaya, termasuk kepada

\footnotetext{
${ }^{6}$ Di antara tahapan-tahapan (thoriqah) dakwah yang di maksud adalah : 1) dakwah sembunyisembunyi; 2) dakwah terang-terangan kepada keluarga; 3) dakwah terang-terangan dengan menghindari permusuhan ; dan 4) dakwah terang-terangan melalui berbagai perundingan damai, jihad atau peperangan, dan lain-lain.

${ }^{7}$ Antariksa, W.F. (2017). Penerapan Manajemen Strategi dalam Dakwah Nabi Muhammad Saw dalam Jurnal J-MPI, 2(1), hlm, 32.
} 
beberapa tokoh kunci (elite quraisy). Setidaknya tokoh-tokoh utama pada periode Mekkah yang bersedia menerima dan menemani perjuangan dakwah Rosulullah Saw seperti Abu Bakar Ash-shidiq, Khadjizah dan Ali bin Abi Thalib ${ }^{8}$.

Karakteristik dakwah pada periode Mekkah selain lebih banyak menggunakan media lisan (khitobah), dakwah Islam disampaikan dalam kondisi umat Islam masih lemah. Sehingga, Rosulullah beserta para sahabat lebih banyak melakukan strategi defensif (bertahan) untuk menguatkan fondasi ketauhidan umat Islam. Selain itu, dari sisi perencanaan, dakwah Rosulullah Saw dilakukan secara bertahap yang meliputi dakwah invividu (fardiyah), dakwah kelompok (hizbiyah) dan dakwah kenegaraan menjelang fase hijrah dari Mekkah ke Madinah ${ }^{9}$.

Pada fase dakwah Individu sejak diturunkannya wahyu pertama sampai menjelang hijrah ke Madinah, beberapa dakwah khitobah yang dilakukan oelh nabi Muhammad Saw antara lain : 1) memulai dakwah melalui lisan kepada keluarganya terdekat seperti Khadjizah dan Ali bin Abi Thalib; 2) dakwah melalui lisan yang disampaikan secara sembunyi kepada karib keluarga lainnya; 3) dakwah bil-lisan kepada keluarga besar nabi Muhammad Saw yang hadir secara terbuka; 4) dakwah bil-lisan kepada para kabilah dari luar yang datang ke Mekkah; 6) dakwah bil-kitabah kepada raja Habasyah dan Raja Thaif melalui surat; 5) dakwah bil-lisan dengan mengutus umat Islam untuk hijrah ke Habasyah dan mendakwahi rajanya; 6) dakwah bil-lisan dengan memerintahkan umat Islam hijrah ke Thaif dan mendakwahi pimpinannya.

\section{Manajemen Dakwah Periode Madinah}

Periode Madinah ditandai dengan hijrahnya nabi Muhammad Saw beserta umat Islam dari Mekkah ke Madinah. Pada kondisi ini, hijrahnya umat Islam menandakan kekuatan umat Islam semakin besar. Kondisi internal umat Islam

\footnotetext{
${ }^{8}$ Cucu. (2016). Manajemen Dakwah Rasulullah: Analisis Dakwah Nabi di Kota Mekkah dalam Jurnal Tadbir, 1(2), hlm, 30.

${ }^{9}$ Basri, H. (2014). Manajemen Dakwah Rasul Saw di Mekkah dalam Jurnal Al-Munzir, 7(2), hlm, 32.
} 
semakin solid dengan fondasi ketauhidan yang kuat. Akan tetapi, pada sisi eksternal, umat Islam masih mengalami berbagai ancaman yang datang dan dilakukan oleh kaum kafir quraisy Mekkah.

Sejarah dakwah pada periode Madinah dilakukan melalui beberapa tahapan penting, di antaranya dimulai dari mempersaudarakan antara kaum anshar dan muhajiran, dilanjutkan dengan membangun masjid sebagai pusat dakwah umat Islam dan diakhiri dengan dakwah dalam konteks kenegaraan dengan menerapkan prinsip-prinsip nilai Islam dalam fondasi kenegaraan. Dakwah dawlah ini dilakukan oleh Rosulullah baik melalui metode lisan secara terbuka dan terang-terangan (Manajemen Dakwah Dawlah secara internal) maupun melalui metode tulisan dengan mengirimkan seruan bertauhid kepada negara-negara di luar Arab (Manajemen Dakwah Dawlah secar eksternal) ${ }^{10}$.

Secara internal, kondisi umat Islam pada periode Madinah sudah semakin kuat. Beberapa pelaksanaan dakwah yang dilakukan oleh Rosulullah Saw di antaranya : 1) dakwah bil-lisan dengan mempersaudarakan antara anshor dan muhajirin; 2) dakwah sosial dengan menerapkan prinsip-prinsip persaudaraan, persamaan, toleransi, tolong menolong dan keadilan; 3) dakwah perundingan melalui kesepakatan piagam Madinah; 4) dakwah perundingan melalui Perjanjian Hudaibiyah; 5) dakwah bil-qital melalui peperangan di antaranya perang Badar, Uhud dan Khandak; 6) dakwah bil-kitabah melalui pengiriman surat dan da'i ke luar negeri ${ }^{11}$.

Dari keenam tahapan dakwah pada periode Madinah di atas, menunjukkan bahwa dakwah bil-kitabah menjadi cara atau metode alternatif dilakukan oleh Rosulullah Saw pada beberapa kondisi tertentu. Misalnya dakwah bil-kitabah melalui perundingan damai antara Kaum Muslim dan Kafir Quraisy yang termaktub dalam Piagam Madinah, dakwah bil-kitabah sebagai bentuk gencatan senjata setelah mengalami beberapa kali peperangan

\footnotetext{
${ }^{10}$ Basri, H. (2015). Manajemen Dakwah Nabi Saw di Madinah dalam Jurnal Al-Munzir, 8(2), hlm, 186.

${ }^{11}$ Antariksa, W.F. (2017). Penerapan Manajemen Strategi dalam Dakwah Nabi Muhammad Saw dalam Jurnal J-MPI, 2(1), hlm, 35-36.
} 
yang termaktub dalam perjanjian Hudaibiyah, dan dakwah bil-kitabah melalui pengiriman surat kepada negeri-negeri di luar Arab. Setidaknya terdapat delapan kali pengiriman surat kepada para penguasa-penguasa di luar madinah, diantaranya surat kepada Najasyi, raja Habasyah, kepada Muqauqis, raja Mesir, kepada Kisra, raja Persia, kepada Qaishar, raja Romawi, kepada Al-Mundzir bin Sawa, kepada Haudzan bin Ali Al Hanafi, pemimpin Yamamah, kepada Al Harits bin Abu Syamr Al Ghassani, pemimpin Damaskus, dan kepada Raja Uman.

Dengan demikian, sejarah dakwah periode Mekkah dan Madinah menunjukkan bagaimana pemetaan, perencanaan, pelaksanaan dan pengawasan (Manajemen) dakwah yang dilakukan oleh Rosulullah senantiasa memperhatikan berbagai kondisi pelaku dakwah, segmentasi objek dakwah, pemilihan pesan, metode dan media dakwah serta pembacaan terhadap kondisi sosio-kultural masyarakat arab pada masa itu. Pada hakikatnya manajemen dakwah Rosulullah Saw pada periode Mekkah maupun Madinah mengandaikan pelaksanaan dakwah secara lisan dan tulisan yang diderivasikan ke dalam berbagai teknik pelaksanaan dakwah, termasuk melalui perjanjian damai, perundingan damai, negosiasi dan manajemen konflik.

\section{Signifikansi Perundingan Damai Dalam Pengembangan Dakwah}

Nabi Muhammad Saw telah melakukan berbagai perundingan atau negosiasi terutama dengan kaum kafir quraisy baik di Mekah maupun Madinah. Perundingan ini dilakukan dalam rangka menjaga harkat dan martabat manusia sekaligus menguatkan kohesivitas sosial di antara masyarakat Arab pada saat itu. Dalam konteks dakwah Islam, perundingan dilakukan melalui berbagai upaya sehingga tercipta keharmonisan sosial. Pada umumnya, perundingan terjadi antara dua pihak yang saling berkonflik. Upaya untuk mengelola konflik 
(manajemen konflik) harus dilakukan sehingga terwujud kesepakatan yang saling menguntungkan satu sama lain ${ }^{12}$.

Berdasarkan bentuknya, konflik dapat terjadi pada pada tataran personal, komunal maupun kelembagaan. Dalam konteks dakwah, Rosulullah Saw sebagai teladan umat seringkali mendapati kondisi konflik yang terjadi di antara para sahabat maupun konflik dalam skala besar yang berujung pada kekerasan dan peperangan dengan kaum kafir quraisy. Contoh kasus, konflik yang tejadi antara tentang informasi yang memberitakan istrinya, Aisyah. Di antara para sahabat ada yang mempercayai berita tersebut ada pula yang tidak. Bahkan dalam sejarah Islam, konflik ini berujung pada peperangan yang dikenal dengan perang jamal.

Selain itu, dari mulai diturunkannya wahyu Allah Swt, nabi Muhammad Saw beserta para sahabat tidak terlepas dari berbagai ancaman, teror, intimidasi dan pertentangan (konflik) dengan kaum kafir quraisy. Pada titik ini, ancaman tersebut dimaknai sebagai sebuah ujian dari kesungguhan keimanan dan ketauhidan yang dimiliki oleh umat Islam dalam memperjuangkan risalah Islam. Dalam skala komunal, intimidasi ini berujung pada kekerasan, penganiayaan bahkan perang. Pada masa-masa tertentu, kebijakan strategis dakwah Rosulullah Saw dalam menghadapi berbagai situasi yang mengancam tersebut tidak jarang berakhir dengan perundingan atau negosiasi. Hal ini dilakukan selain sebagai bentuk pertahanan dan pemeliharaan mentalitas umat Islam, juga dilakukan sebagai strategi eksternal dalam menjaga ritme perjuangan dakwah Islam.

Penerapan perundingan damai (negosiasi) dalam pengembangan dakwah Islam sudah sejak dulu dilakukan oleh Rosulullah Saw. Dalam sejarah dakwah Islam tercatat beberapa perundingan yang dilakukan oleh Rosulullah Saw baik pada periode Mekkah maupun pada periode Madinah. Pada dasarnya perundingan ini dilakukan di atas nilai-nilai keislaman dengan orientasi terciptanya tatanan masyarakat harmonis. Terdapat beberapa prinsip pengembangan dakwah Islam melalui teknik perundingan ini, antara lain : 1) Perundingan dalam melerai konflik dilakukan dengan prinsip tabayyun. Yakni prinsip menguraikan masalah

${ }^{12}$ Waeduloh, H. (2014). Manajemen Konflik Dalam Perspektif Islam dalam Jurnal Tabligh, 15(1), hlm, 101. 
melalui pengumpulan informasi yang melibatkan berbagai pihak; 2) Setelah proses tabayyun, perundingan dalam pengembangan dakwah Islam dilakukan melalui prinsip musyawarah. Yakni mencari kesepakatan atas berbagai kemelut yang melibatkan dua pihak yang saling bertentangan; dan 3) Perundingan diakhiri dengan ishlah (perdamaian) dengan menjunjung tinggi kesepakatan yang telah ditetapkan bersama ${ }^{13}$.

Perundingan dipandang sebagai salah satu ragam manajemen dakwah yang dilakukan oleh Rosulullah Saw pada kondisi tertentu. Hal ini dilakukan terutama ketika melibatkan musuh-musuh Islam yang senantiasa menentang bahkan melawan dakwah Islam. Namun demikian, selain orientasinya untuk menyelematkan umat Islam dari potensi konflik yang mungkin terjadi, perundingan dilakukan juga sebagai upaya mewujudkan masyarakat yang humanis dan harmonis. Nabi Muhammad Saw diutus sebagai pemimpin umat manusia. Maka pada titik ini nabi Muhammad Saw memainkan peran sentral dalam membangun fondasi kehidupan sosial yang sesuai dengan nilai-nilai Islam, terutama nilai perdamaian dan persatuan.

Tabel di bawah ini merupakan periodesasi sejarah, dimana perundingan damai dilakukan oleh Rosulullah Saw dalam melaksanakan dakwah Islam. Perundingan-perundingan ini dilakukan baik pada masa Mekkah maupun Madinah untuk memperkuat jalinan sosial dan kerjasama umat Islam secara internal dalam membumikan nilai-nilai tauhid yang terdapat dalam ajaran Islam.

Tabel 1.

Manajemen Dakwah melalui Perundingan Pada Masa Rosulullah Saw

\begin{tabular}{lccl}
\hline No & Perjanjian & Waktu & \multicolumn{1}{c}{ Latar Belakang } \\
\hline 1 & Baiat Aqabah I & $621 \mathrm{M}$ & Perjanjian ini dilakukan antara Rosulullah \\
& & Saw dengan 12 orang dari Madinah \\
& & (Yastrib). Perjanjian ini dikenal pula dengan \\
& & "Perjanjian Wanita" karena terdapat wanita \\
& & pada perjanjian ini. Perjanjian ini adalah \\
& & baiat yang dilakukan oleh 12 orang tersebut \\
& & kepada Rosulullah Saw di sebuah tempat \\
& &
\end{tabular}

\footnotetext{
${ }^{13}$ Waeduloh, H. (2014). Manajemen Konflik Dalam Perspektif Islam dalam Jurnal Tabligh, 15(1), hlm, 100-101.
} 


\begin{tabular}{|c|c|c|c|}
\hline & & & bernama Aqabah. \\
\hline 2 & $\begin{array}{l}\text { Baiat } \\
\text { II }\end{array}$ & $622 \mathrm{M}$ & $\begin{array}{l}\text { Perjanjian ini dilakukan oleh Rosulullah } \\
\text { Saw bersama } 73 \text { orang pria dan } 2 \text { orang } \\
\text { wanita. Perjanjian ini terjadi pada tahun } \\
\text { ketiga belas kenabian. Perjanjian ini pada } \\
\text { dasarnya sama dengan perjanjian Aqbah I, } \\
\text { yakni sebagai bentuk baiat umat Islam } \\
\text { terhadap nabi Muhammad Saw sebagai } \\
\text { utusan Allah Swt. }\end{array}$ \\
\hline 3 & $\begin{array}{l}\text { Piagam } \\
\text { Madinah }\end{array}$ & $622 \mathrm{M}$ & $\begin{array}{l}\text { Piagam Madinah atau dikenal pula dengan } \\
\text { istilah Dustur al-Madinah dan Shahifah al- } \\
\text { Madinah merupakan perundingan tertulis } \\
\text { yang dilakukan dengan kafir Quraisy. } \\
\text { Piagam Madinah dipandang sebagai } \\
\text { konstitusi pertama dalam konteks } \\
\text { kenegaraan yang mengatur kehidupan } \\
\text { masyarakat Arab secara bersama dengan } \\
\text { melibatkan kaum muslim dan non muslim. } \\
\text { Piagam Madinah terdiri dari } 47 \text { pasal } \\
\text { dimana } 23 \text { klausa di antaranya } \\
\text { membicarakan tentang hubungan antara } \\
\text { umat Islam dengan sesama umat Islam yaitu } \\
\text { antara Ansar dan Muhajirin. Sedangkan } 24 \\
\text { pasal lagi membicarakan tentang hubungan } \\
\text { umat Islam dengan umat non Islam yaitu } \\
\text { Yahudi. }\end{array}$ \\
\hline 4 & $\begin{array}{l}\text { Perjanjian } \\
\text { Hudaibiyah }\end{array}$ & $628 \mathrm{M}$ & $\begin{array}{l}\text { Perjanjian ini dilakukan pada periode } \\
\text { Mekkah. Yakni perjanjian yang } \\
\text { ditandatangai antara Rosulullah Saw } \\
\text { dengan kaum Musyrikin Quraisy. } \\
\text { Hudaibiyah merupakan nama tempat } \\
\text { dimana perjanjian ini ditandatangani. }\end{array}$ \\
\hline 5 & Hilf Al-Fudul & $586 \mathrm{M}$ & $\begin{array}{l}\text { Perjanjian ini adalah perjanjian bisnis yang } \\
\text { ditandatangani penduduk Mekkah, } \\
\text { termasuk Rosulullah Saw. Perjanjian ini } \\
\text { didasari dengan orientasi adanya keadilan } \\
\text { secara ekonomi antar penduduk Mekkah. } \\
\text { Perjanjian ini oleh para pakar dianggap } \\
\text { sebagai wujud etika Islam. Hilf Al-fudul } \\
\text { artinya perjanjian mulia. Sebab melalui } \\
\text { perjanjian ini penduduk Mekkah melakukan } \\
\text { kontrol sosial dalam keberlangsungan } \\
\text { sistem ekonominya. Sehingga terjadi } \\
\text { pemerataan atau keadilan. }\end{array}$ \\
\hline
\end{tabular}

(Sumber : Diolah dari berbagai sumber 2018) 
Pada tabel 1, dapat dilihat bagaimana signifikansi perundingan dalam manajemen dakwah Islam. Perjanjian-perjanjian yang dilakukan oleh Rosulullah Saw beserta para sahabat menunjukkan bagaimana pentingnya sebuah perencanaan dan strategi dalam menyampaikan risalah Islam. Untuk mencapai cita-cita dakwah Islam dalam membangun peradaban umat di atas fondasi ketauhidan, maka diperlukan perencanaan dan strategi yang matang. Perundingan-perundingan di atas adalah wujud bagaimana tata kelola dakwah Islam dilakukan oleh Rosulullah dengan menganalisis berbagai kemungkinan dan mempertimbangkan berbagai kebutuhan di antara berbagai pihak.

Dengan merujuk pada berbagai bentuk perjanjian atau perundingan damai yang dilakukan oleh Rosulullah Saw, maka setidaknya terdapat beberapa prinsip yang harus diperhatikan agar perundingan damai ini menghasilkan kesepakatan yang dapat mengakomodir berbagai pihak yang berkepentingan. Di antaranya : 1) prinsip kesamaan dalam berpendapat, dimana setiap pihak memiliki kebebasan dan hak yang sama untuk menyatakan pendapat; 2) Proses pengumpulan informasi yang utuh dari berbagai pihak, sehingga dalam perumusan kesepakatan dapat mengakomodir berbagai kepentingan yang diinginkan; 3) Prinsip lapang dada, yakni siap menerima berbagai kesepakatan yang ditetapkan sekalipun tidak memuaskan; 4) Komitmen terhadap etika dialog, dimana setiap pihak yang berunding menghindari berbagai perkataan atau perbuatan yang dapat menyinggung pihak lain; 5) Menyebutkan kesepakatan bersama dan menjunjung tinggi hasil kesepakatan di atas tanggung jawab dan kesadaran untuk kepentingan bersama.

\section{Penerapan Perundingan sebagai Metode Dakwah di Era Kontemporer}

Piagam Madinah merupakan perlembagaan tertulis pertama yang dibentuk oleh Nabi Muhammad s.a.w sebagai satu peraturan atau sistem perundangan untuk mengatur tata hubungan sosial di Madinah antara umat Islam dan non muslim. Nabi Muhammad Saw menggunakan beragam pendekatan dalam pembentukan piagam Madinah ini. Prinsip toleransi, kesederhanaan, kesederajatan, dan persamaan (equality) dijadikan pegangan oleh nabi 
Muhammad Saw dalam membentuk piagam Madinah. Sebab, piagam Madinah menjadi dasar dalam proses sosial yang menyangkut kehidupan masyarakat Madinah pada waktu itu dalam berbagai aspek kehidupan, baik kehidupan sosial, agama, budaya, ekonomi, maupun politik.

Multikulturalisme masyarakat Madinah pada waktu itu mendorong nabi Muhammad Saw untuk membuat suatu perundingan yang didasarkan pada prinsip keterbukaan dan toleransi untuk mengatur kehidupan yang harmonis. Beliau memandang memandang perlu meletakkan aturan pokok tata kehidupan bersama di Madinah agar terbentuk kesatuan hidup di antara seluruh penduduknya. Piagam ${ }^{14}$ itu menghimpun prinsip-prinsip dan dasar-dasar tata kehidupan bermasyarakat, kelompok-kelompok sosial Madinah, jaminan hak, dan ketetapan kewajiban. Piagam Madinah itu juga mengandung nilai-nilai kebebasan sebagai prinsip pelaksanaan peribadatan setiap kelompok, interaksi sosial di antara kelompok, kewajiban bersama dalam mempertahankan dan menghargai hak hidup masing-masing kelompok, dan lain sebagainya. Hal ini merupakan bagian dari visi kepemimpinan Rosulullah Muhammad Saw dalam membangun peradaban yang didasarkan pada nilai-nilai kebersamaan, persamaan, keadilan, toleransi dan integratif. Nabi Muhammad Saw menjadi prototipe pemimpin yang berhasil menyatukan dan mengorganisir kelompok-kelompok masyarakat yang berbeda menjadi satu bagian negara yang berdaulat. Dengan begitu, nabi Muhammad Saw telah melaksanakan proses siyasah menjadi seorang pemimpin semua golongan tanpa menghilangkan spirit dan nilai-nilai keislaman yang bertujuan untuk mencapai kehendak kolektif ${ }^{15}$.

Pada waktu itu, kemajemukan masyarakat dan sikap bermusuhan satu golongan terhadap golongan lain sangat tampak dalam pandangan nabi Muhammad Saw di Madinah. Oleh karena itu, nabi Muhammad memandang perlu untuk menertibkan interaksi sosial di kalangan masyarakat. Nabi

\footnotetext{
${ }^{14}$ Ahmad Sukardja, Piagam Madinah dan Undang-undang Dasar 1945. Jakarta : Penerbit UI, 1995 : hal. 2. Terdapat beberapa versi penyebutan Piagam Madinah, misalnya "Charter"(Nicholson), "Agreement”(Philip K. Hitti), "Treaty"(Majid Khadduri), "Piagam"(Zainal Abidin Ahmad) dan "The Constitution of Medina"(Montgomery Watt).

15 J. Suyuthi Pulungan, Prinsip-Prinsip Pemerintahan dalam Piagam Madinah Ditinjau dari Pandangan al-Qur'an, (Jakarta: Rajawali Pers, 1996), hlm. 5.
} 
memandang perlu dirumuskan sebuah aturan yang didasarkan atas kesepakatan bersama (musyawarah) dalam menata dan mengendalikan kehidupan sosial sehingga terciptanya kehidupan yang harmonis (islah) antar berbagai golongan yang ada. Pada titik ini, visi nabi Muhammad Saw menjadi wasilah terwujudnya tatanan kehidupan yang harmonis yang mengatur berbagai aspek kehidupan, baik agma, politik, ekonomi, sosial dan budaya.

Beberapa langkah awal yang dilakukan nabi Muhammad bertujuan untuk membangun kemasyarakatan yang dapat memberikan kenyaman, ketenangan, ketertiban dan perdamaian satu sama lain. Setidaknya, ada dua langkah yang dilakukan Muhammad semasa hijrah ke Madinah. Pertama, membangun masjid. Masjid menjadi pusat aktifitas dan dakwah umat Islam. Pada satu sisi, masjid berperan sebagai ruang sentral dalam peningkatan spiritualitas umat Islam. Pada sisi lain, masjid memiliki peran signifikan dalam menyatukan umat. Masjid berperan sebagai ruang publik jamaah dalam menjalankan aktifitas sosialnya ${ }^{16}$. Kedua, mewujudkan persaudaraan (ukhuwah) yang didasarkan pada nilai-nilai ketauhidan antara kaum Muhajirin (Mekah) dan Anshar (Madinah).

Dua upaya besar tersebut diwujudkan sebagai bentuk konsolidasi internal umat Islam. Sementara langkah ketiga ditujukan kepada seluruh penduduk Madinah untuk membina kekuatan secara eksternal. Nabi menginisiasi terwujudnya konsolidasi global yang menghimpun seluruh kekuatan masyarakat Madinah. Perundingan damai yang disepakati sebagai bentuk perjanjian antara kaum muslim dan komunitas yahudi menekankan adanya persatuan erat, menjamin kebebasan beragama, menekankan kerjasama dan persamaan hak dan kewajiban semua golongan secara sosial dan politik, mewujudkan pertahanan dan perdamaian, dan menetapkan wewenang bagi Nabi sebagai pemimpin bersama yang dapat menengahi dan memutuskan segala perbedaan pendapat dan perselisiihan yang timbul di antara semua golongan ${ }^{17}$.

\footnotetext{
${ }^{16}$ Didin Hafidhuddin, Pendayagunaan Potensi Masjid: Upaya Meningkatkan Keejahteraan Ummat, Makalah disampaikan pada Seminar Nasional dalam rangka Milad Setengah Abad Masjid Syuhada' pada tanggal 21 September 2002.

${ }^{17}$ J. Suyuthi Pulungan, ibid. hlm. 64.
} 
Konsolidasi eksternal yang dilakukan oleh nabi Muhammad Saw ini merupakan bagian integral dari metode dakwah nabi dalam menyebarkan risalah Islam. pada saat nabi Muhammad Saw hijrah ke Madinah, setidaknya nabi Muhammad Saw telah memiliki basis kekuatan yang mumpuni dalam menerapkan prinsip-prinsip syariat Islam. pertama, mayoritas masyarakat Madinah yang siap dan bersedia menerima dakwah Islam menjadikan nabi Muhammad leluasa dalam membina dan menerapkan aturan Islam. kedua, dominasi dari masyarakat non muslim yang tidak terlalu kuat dan mengintimidasi menjadikan nabi Muhammad leluasa untuk mengatur strategi dalam menertibkan kehidupan sosial masyarakat Madinah pada waktu itu. Oleh sebab itu, inisiasi pembentukan piagam Madinah dalam perspektif politik dipandang sebagai bagian dari siyasah dakwah nabi dalam menerapkan aturan Islam dalam konteks tata hubungan sosial di Madinah. Maka dua kekuatan inilah yang mendorong nabi Muhammad untuk melakukan konsolidasi eksternal yang melibatkan non muslim dalam membangun kesatuan sosial dan politik di tengah multikulturalisme masyarakat Madinah.

Piagam Madinah ini secara lengkap diriwayatkan oleh Ibn Ishaq ${ }^{18}$ dan Ibn Hisyam $^{19}$ di dalam kitabnya Sirah al-Nabiyy, dua penulis muslim yang mempunyai nama besar dalam bidangnya. kedua penulis tersebut meriwayatkan sejarah piagam Madinah secara komprehensif dan sistematis, sehingga dalam hal ini menjadi rujukan dalam mendalami sejarah dakwah Rosulullah Saw. Dari perspektif bahasa, penulisan dan pemilihan gaya bahasa dalam piagam Madinah mengindikasikan bagaimana keterampilan seorang nabi Muhammad Saw dalam mengakomodir berbagai kepentingan yang ada. Sehingga, banyak kalangan menilai bahwa kandungan piagam Madinah sebagai aturan konstitusional pertama yang tidak bisa diragukan dalam konteks membangun kesadaran emansipatif secara komunal. Setiap kalimat atau pasal yang termaktub dalam

\footnotetext{
${ }^{18}$ Ibn Ishaq $(85-150 \mathrm{H})$ lahir dan dibesarkan di Madinah. Ia seorang hafidz, penulis terpercaya, penghimpun kabar-kabar Rasulullah.

${ }^{19}$ Ibn Hisyam (wafat $218 \mathrm{H}$ ) lahir di Bashrah dan meninggal di Mesir. Ia menyusun beberpa kitab tarikh. Ia meneriwa riwayat hidup Nabi dari Ibn Ishaq melalui sahabat Ibn Ishaq bernama Abu Muhammad Ziyad ibn Abdillah ibn al-Tufail al-Buka'i, seorang hafidz yang terpercaya.
} 
piagam Madinah mengandung spirit sosiologis dan historis yang unggul pada zamannya.

Kalimat-kalimat shahîfah seperti tercantum dalam kitab Sirah al-nabiyy Ibn Hisyam, tersusun secara bersambung, tidak terbagi atas pasal-pasal dan bukan berbentuk syair. Bismillâhirrahmânirrahîm tertulis pada awal naskah, disusul dengan rangkaian kalimat berbentuk prosa. Ilmuwan Muslim dan non Muslim banyak yang mengutip seluruh naskha itu yang dibagi atas pasal-pasal. Muhammad Hamidullah misalnya, mengutip teks itu selengkapnya dan membaginya atas 47 pasal $^{20}$.

Piagam Madinah menjadi bukti sejarah otentik yang merekam berbagai kondisi sosial-politik serta komposisi penduduk Madinah yang multikultural. Piagam ini menjadi dokumen perjanjian antara Anshar, Muhajirin dan komunitas Yahudi (Treaty of Alliance). Perjanjian trialiansi ini dilakukan dengan memandang dua alasan utama, yaitu : pertama, perjanjian antara ketiga golongan ini adalah sebuah usaha nabi Muhammad Saw dalam melakukan manajemen konflik sekaligus rekonsiliasi antara suku-suku yang ada di Madinah dalam mewujudkan integrasi nasional demi terwujudnya peradaban yang memberikan hak dan kewajiban bersama. Dengan kata lain, rekonsiliasi ini menjadi fondasi dalam mewujudkan sebuah dawlah yang berdiri di atas kepentingan bersama. Kedua, rekonsiliasi ini menghendaki adanya integrasi dan toleransi bersama suku-suku Yahudi ${ }^{21}$. Namun demikian, penghargaan terhadap nilai-nilai keagamaan di masing-masing pihak mendapat pemeliharaan yang tegas. Sehingga dalam hal ini tidak pernah diperkenankan percampuran peribadatan agama antar satu kelompok dengan kelompok lainnya.

Penetapan perundingan yang terdapat dalam piagam Madinah merupakan wujud keberhasilan nabi Muhammad Saw dalam membangun masyarakat yang hidup berdampingan di atas perbedaan agama : Muslim, Yahudi dan penganut Paganisme. Hal ini menandakan bagaimana figur dan karakteristik nabi

\footnotetext{
${ }^{20}$ Ahmad Sukardja, Piagam Madinah dan Undang-Undang Dasar 1945: Kajian Perbandingan tentang Dasar Hidup Bersama dalam Masyarakat Yang Majemuk, (Jakarta: Penerbit Universitas Indonesia, 1995), hlm. 45

${ }^{21}$ Ibid. hlm, 55
} 
Muhammad Saw yang didaulat sebagai pemimpin umat, pemimpin setiap manusia. Nabi Muhammad Saw merumuskan perundingan ini dengan memperhatikan kemashlahatan bersama, bukan hanya kepentingan kaum muslim, tetapi juga kepentingan non muslim. Paradigma sosial yang inklusif-egaliter menjadi pola pendekatan yang diambil oleh nabi dalam membaca dan memetakan realitas sosial serta sebagai bagian dari langkah politik yang visioner. Selain itu, perundingan inipun memperhatikan kebiasaan-kebiasaan (konvensi dan tradisi) yang hidup di kalangan masyarakat Madinah. Hal ini dilakukan melalui pengakuan dan kesepakatan bersama untuk menjunjung nilai-nilai tradisi lokal yang tidak bersebrangan dengan prinsip-prinsip agama. Fakta historis ini, menurut Phillip K.Hitti, merupakan wujud kredibilitas dan kapasitas nabi Muhammad dalam melakukan perundingan dan konsolidasi dengan masyarakat Madinah yang majemuk ${ }^{22}$. Oleh karenanya, ketetapan-ketetapan Piagam Madinah menjamin hak semua kelompok sosial dan persamaan hukum dalam segala urusan publik.

Fakta historis yang berlangsung kurang lebih empat belas abad yang lalu ini tidak hanya merekam kondisi sosio-kultural-politik yang terjadi pada masa masyarakat Madinah saja, tetapi melalui kajian dan pendalaman para ahli menempatkan piagam Madinah sebagai konstitusi pertama yang mampu merekatkan kesatuan masyarakat yang berbeda secara budaya dan agama. para ahli ${ }^{23}$ memandang bahwa ketetapan dalam perundingan sejarah dakwah nabi melalui piagam Madinah ini dapat diadopsi bahkan diterapkan dalam dinamika kehidupan masyarakat hari ini. Dinamika dan perkembangan kehidupan manusia sedikit banyak merubah struktur interaksi manusia. perkembangan teknologi berpengaruh secara signifikan terhadap nilai-nilai budaya masyarakat. Sehingga, dapat kita temui perubahan pergeseran sistem sosial dalam kehidupan manusia

\footnotetext{
${ }^{22}$ Phillip K. HItti, Capital Cities of Arab Islam, (Minuapolis: University of Minuesofa, 1973). Hlm, 35-36.

${ }^{23}$ Misalnya Montgomery Watt yang menyebut Piagam Madinah dengan sebutan "The Constitution of Medina", R.A Nicholson menyebut sebagai "Charter", Majid Khadduri dengan sebutan "Treaty" dan Philip K.Hitti dengan sebutan "Agreement".
} 
sehari-hari. Kemajemukan masyarakat hari ini menghadirkan tantangan sekaligus peluang baru dalam sistem kehidupan manusia.

Dalam konteks dakwah, upaya mendalami dan memahami kondisi serta kultur sosio historis madh'u menjadi keharusan bagi para pelaksana dakwah. Sebab, bagaimanapun dakwah adalah upaya yang dilakukan untuk merubah kondisi dan keadaan masyarakat dari berbagai latar sosial dan budaya menuju keadaan dan kondisi terbaik berdasarkan pada risalah ilahi (al-qur'an) dan teladan nabi (as-sunnah). Keharusan memahami kondisi madh'u menjadi alasan bagi da'I dalam mengembangkan kemampuan dalam berpikir, bertindak bahkan berperilaku laiknya madh'u. maka, menjadi penting bagi da'I menempatkan upayanya dalam menyebarkan risalah Islam sesuai dengan medan dakwah atau kebutuhan madh'unya. Kemajemukan masyarakat yang semakin variatif menjadi landasan bagi da'I untuk melaksanakan dakwah suubiyah wa qabailiyah (dakwah pada masyarakat yang beragam secara budaya, adat maupun keyakinan). Pada posisi ini, da'I melaksanakan dakwah eksternal dengan mempertimbangkan aspek-aspek psiko-sosial yang menjadi tempat berinteraksi madh'u dengan lingkungannya.

Kemajemukan masyarakat hari ini menjadi tantangan bagi setiap da'i dalam menyusun dan/atau merumuskan strategi dakwah yang sesuai dengan perkembangan zaman. Secara historis, pembentukan piagam Madinah pada masa Rosulullah Saw menjadi bukti bagaimana kecerdasan yang dimiliki oleh nabi Muhammad Saw dalam menyampaikan risalah Islam kepada masyarakat Madinah/Yastrib. Kondisi sosio-kultural-politik masyarakat Madinah pada waktu itu tidak jauh berbeda dengan kondisi masyarakat hari ini, terutama dalam konteks keindonesiaan. Indonesia merupakan negara multicultural yang didalamnya kurang lebih berhimpun 500 suku bangsa dengan lebih dari 300 bahasa daerah. Ditinjau dari sisi keyakinan, di Indonesia terdapat enam agama yang diakui ditambah dengan berbagai aliran kepercayaan yang masih hidup dan bertahan di tengah masyarakat Indonesia. Atas dasar ini, Islam mengajarkan penyampaian risalah Islam dengan cara damai, yang menitikberatkan pada 
penyampaian pesan-pesan ilahiah yang ramah dan memberikan kasih sayang bagi setiap umat manusia. salah satu strategi dakwah yang dapat diterapkan dalam konteks keindonesiaan adalah nilai-nilai yang termaktub dalam piagam madinah sebagai sebuah persetujuan yang dibentuk untuk mengatur hubungan antara kaum anshar, muhajirin dan masyarakat yahudi.

Berdasarkan kajian yang penulis lakukan terhadap teks piagam madinah setidaknya terdapat enam pokok nilai yang dapat diterapkan oleh para da'I dalam menyebarkan risalah Islam sesuai kondisi sosio-kultural masyarakat Indonesia. Penerapan nilai-nilai pokok ini dilakukan sebagai sebuah upaya untuk mentransmisikan dakwah Islam dalam konteks keberagaman masyarakat. Adapun nilai-nilai piagam Madinah sebagai sebuah penerapan strategi dakwah Islam adalah : (1) Nilai Toleransi sebagai Perekat Sosial. Nilai toleransi yang dibangun bersama komunitas Yahudi dan Nashrani di Yastrib merupakan bagian dari strategi dakwah Rosulullah Saw dalam menebarkan risalah Islam. (2) Nilai Humanitas sebagai Kesadaran Hidup Bermasyarakat. Penerapan nilai humanitas dalam proses pelaksanaan dakwah hari ini menjadi penting mengingat problematika dakwah kontemporer menyiratkan adanya keharusan untuk mengedepankan nilai-nilai Islam sebagai ajaran yang menghendaki terciptanya perdamaian dan rahmah bagi sekalian manusia. (3) Nilai Ketuhanan (Transendensi) sebagai Fondasi Kehidupan. Ketetapan piagam Madinah tentang kebebasan beragama dan pengakuan akan eksistensi komunitas-komunitas agama yang ada, diikuti pula dengan ketetapan-ketetapan yang mengatur hubungan sosial-politik di antara pemeluk agama-agama tersebut. Hubungan-hubungan tersebut baik berkaitan dengan kebebasan menjalan urusan agama masingmasing, hubungan pertahanan dan keamanan, di bidang belanja peperangan, maupun dalam bidang kehidupan sosial yang melarang adanya pembunuhan dan penganiayaan satu sama lain. (4) Nilai Liberasi sebagai Manifestasi Kreasi. Ketetapan Piagam Madinah menghendaki adanya penjaminan kebebasan (liberasi) bagi seluruh masyarakat dalam menjalankan aktifitas kehidupannya. Prinsip liberasi ini dijadikan sebagai salah satu pedoman dalam 
mengaktualisasikan nilai-nilai ketuhanan yang berdimensi insaniah. Liberasi dimaknai sebagai kebebasan yang dapat mengantarkan manusia menuju posisi yang paling tinggi sebagai wakil Tuhan (kholifah).

\section{E. Penutup}

Secara sosial-politik piagam Madinah merupakan naskah otentik yang menjadi jawaban sekaligus sebagai jalan tengah dalam mengakomodir realitas sosial yang beragam di Madinah. Secara global, piagam Madinah sebagai sebuah kesepakatan bersama yang mengikat dan memiliki ketetapan hukum untuk menjalankan kehidupan sosial masyarakat. Heterogenitas masyarakat Madinah bukan menjadi penghalang terwujudnya persatuan dan persaudaraan di antara sesama. Masing-masing golongan memiliki hak yang sama untuk menjalankan kehidupan secara sosial dan ekonomi. Pada sisi lain, setiap kelompok memiliki kewajiban dalam membela Madinah dari setiap potensi gangguan yang ada. Madinah menjadi dawlah yang menghimpun beragam kepentingan masyarakat yang plural dan multikultural agar terintegrasi dalam kesatuan dan kebersamaan tujuan.

Ketetapan piagam Madinah tentang kebebasan beragama dan pengakuan akan eksistensi komunitas-komunitas agama yang ada, diikuti pula dengan ketetapan-ketetapan yang mengatur hubungan sosial-politik di antara pemeluk agama-agama tersebut. Hubungan-hubungan tersebut baik berkaitan dengan kebebasan menjalan urusan agama masing-masing, hubungan pertahanan dan keamanan, di bidang belanja peperangan, maupun dalam bidang kehidupan sosial yang melarang adanya pembunuhan dan penganiayaan satu sama lain.

Dalam konteks dakwah Islam, strategi perundingan damai yang termaktub dalam piagam Madinah dapat dijadikan sebagai salah satu pola manajemen dakwah Islam. Hal ini pernah dilakukan oleh Rosulullah Saw dan terbukti efektif dalam mencapai kohesivitas sosial. Metode dakwah dengan cara perundingan dipandang sebagai salah satu alternatif dalam menyampaikan risalah Islam bagi umat manusia yang memiliki tingkat heterogenitas tinggi. Dalam konteks sejarah Islam, terdapat beberapa perundingan (negosiasi) yang pernah 
dilakukan oleh Rosulullah Saw pada masa kenabiannya, di antaranya perundingan Hilf Al-Fudhul, Baiat Aqabah I, Baiat Aqabah II, Perjanjian Hudaibiyah dan Piagam Madinah.

Perundingan damai yang terkandung dalam Piagam Madinah menjadi salah satu bukti kecerdasan dan kebijaksanaan Rosulullah Saw dalam menyampaikan dakwah Islam. Perundingan damai yang dilakukan oleh Rosulullah melalui piagam Madinah mengandung berbagai ajaran yang harus dijadikan sebagai pedoman bagi setiap muslim dalam mewujudkan keharmonisan sosial dalam kehidupan sehari-hari. Terdapat beberapa nilai-nilai yang terkandung dalam perjanjian piagam Madinah untuk pengembangan dakwah Islam yaitu kepercayaan, adil, jujur, budi bahasa, dan berpikiran terbuka. Nilainilai tersebut dapat dikembangkan oleh para pendakwah dalam proses transformasi sosial. Nilai-nilai dakwah yang terkandung dalam perundingan dakwah Rosulullah Saw di antaranya : (a) penerapan nilai toleransi sebagai perekat sosial; (b) penerapan nilai humanitas sebagai wujud kesadaran hidup bermasyarakat; (c) penerapan nilai ketuhanan (transendensi) sebagai fondasi kehidupan; dan (d) penerapan nilai liberasi sebagai manifestasi kreasi. Keempat nilai-nilai tersebut memiliki signifikansi yang kuat dalam konteks dakwah kontemporer.

Penerapan nilai-nilai moderasi Islam di atas menjadi penting dilakukan dalam menjawab problematika dakwah kontemporer. Hal ini sebagai salah satu ikhtiar untuk mewujudkan kehidupan sosial yang harmonis dan damai di tengah berbagai ancaman perpecahan dan disintegrasi umat. Dalam konteks dakwah, transmisi dan transformasi pesan keislaman ini dengan menerapkan nilai toleransi, persamaan dan kesatuan umat bangsa dan negara merupakan salah satu wujud penerapan kandungan piagam Madinah dalam kehidupan bermasyarakat. 


\section{Daftar Pustaka}

\section{Rujukan Buku}

Abu Jusuf, Ja"qub Ibn Ibrahim, Kitab Al-Kharaj, Cet. 5. Cairo: Al- Matha"eah alSalafiyyah.

Ali, A.M. (2009). Edisi revisi ilmu Dakwah. Jakarta: Prenada Media Group.

Ali, A.M. (2004). Ilmu Dakwah. Jakarta: Kencana.

Asy’ari, dkk. (2004). Pengantar Studi Islam. Surabaya: IAIN Ampel Press.

AS, Enjang \& Aliyudin, M. (2009). Dasar-dasar Ilmu Tabligh. Bandung : Widya Padjadjaran.

Bachtiar, W. (1997). Metodologi Penelitian Ilmu Dakwah. Jakarta: Logos Wacana

Cangra, H. (1998). Pengantar Ilmu Komunikasi. Jakarta: Raja Gravinndo Persada.

Hitti, P.K, (1973). Capital Cities of Arab Islam. Minuapolis: University of Minuesofa.

Ibnu Asakir. Tarikh Dimashq Al-Kabir, jilid I, Ut.2, (Beirut: Dar Al- Masirah, $1399 \mathrm{H} / 1979 \mathrm{M})$.

Muis, A. (2001). Komunnikasi Islam. Bandung: PT . Remaja Rosdakarya

Muthahhari, M. (2006). Stop Anarkisme. Jakarta : AlHuda.

Nasution, H., \& Effendi, B. (2003). Hak Azasi Manusia Dalam Islam. Jakarta : Pustaka Pelajar.

Pawito. (2008). Penelitian Komunikasi Kualitatif. Yogyakarta : LKiS.

Pulungan, J.S. (1996). Prinsip-Prinsip Pemerintahan dalam Piagam Madinah Ditinjau dari Pandangan al-Qur'an. Jakarta : Rajawali Pers.

Rahardjo, D. (2005). Paradigma Alquran. Jakarta : PSAP.

Ruslani. (2000). Masyarakat Kitab dan Dialog Antaragama. Yogyakarta : Bentang Buday.

Sambas, S dkk. (2009). Dimensi Ilmu Tabligh. Bandung : WIdya Padjadjaran.

Smith, S.A. (1971). Constitutional and Administrative Law. London. 
Sukardja, A. (1995). Piagam Madinah dan Undang-Undang Dasar 1945: Kajian Perbandingan tentang Dasar Hidup Bersama dalam Masyarakat Yang Majemuk. Jakarta : Penerbit UI.

\section{Rujukan Jurnal}

Antariksa, W.F. (2017). Penerapan Manajemen Strategi dalam Dakwah Nabi Muhammad Saw dalam Jurnal J-MPI, 2(1), hal 28-34.

Basri, H. (2014). Manajemen Dakwah Rasul Saw di Mekkah dalam Jurnal AlMunzir, 7(2), hal 31-40.

Basri, H. (2015). Manajemen Dakwah Nabi Saw di Madinah dalam Jurnal AlMunzir, 8(2), hal 179-196.

Cucu. (2016). Manajemen Dakwah Rasulullah: Analisis Dakwah Nabi di Kota Mekkah dalam Jurnal Tadbir, 1(2), hal 23-44.

Syarnubi. (2016). Manajemen Konflik Dalam Perspektif Islam dan Problematikanya: Studi Kasus di Fakultas Dakwah dan Komunikasi UINSUKA Yogyakarta dalam Jurnal Tadrib, 2(1), hal 1-24.

Yuliyatun \& Tajudin. (2016). Manajemen Dakwah Organisasi Islam: Menjawab Konflik Keberagamaan dan Intoleransi Kaum Radikal dalam Jurnal Tadbir, $1(2)$,

Waeduloh, H. (2014). Manajemen Konflik Dalam Perspektif Islam dalam Jurnal Tabligh, 15(1), hal 91-104. 